\title{
Nine-month course of SARS-CoV-2 antibodies in individuals with COVID-19 infection
}

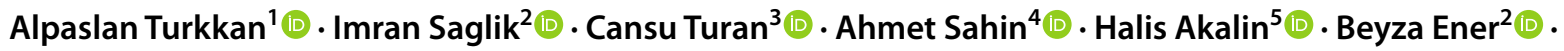 \\ Ates Kara ${ }^{6}$ (D) Solmaz Celebi ${ }^{3}$ (D) Emre Sahin $^{3}$ (1) $\cdot$ Mustafa Hacimustafaoglu ${ }^{3}$ (1)
}

Received: 1 April 2021 / Accepted: 7 July 2021 / Published online: 20 January 2022

(c) The Author(s), under exclusive licence to Royal Academy of Medicine in Ireland 2022

\begin{abstract}
Background The continual course of the pandemic points to the importance of studies on the rate and durability of protective immunity after infection or vaccination.

Aims In this study, we aimed to monitor anti-nucleocapsid (N) and anti-spike (S) antibodies against SARS-CoV-2 nearly 9 months duration after infection.

Methods Anti-nucleocapsid (N) (at 11-15-20-29-38 weeks) and anti-spike antibodies (at 11 and 38 weeks) against SARSCoV-2 were monitored during 38 weeks after the initial symptoms of COVID-19.

Results Of 37 cases between 18 and 57 years old, 54\% were women. The findings showed that anti-N antibodies decreased significantly after the 15 th week (between 15 and 20 weeks, $p=0.016$; 20-29 weeks, $p=0.0009$; and 29-38 weeks, $p=0.049$ ). At the 38th week, mean antibody levels decreased 35\% compared to the 11 th week, and $8 \%$ of the cases turned negative results. Anti-N antibody average level was 56.48 on the 11 th week (the cut-off index threshold $\geq 1$ ). It was estimated statistically that it would decrease to an average of 20.48 in weeks 53-62. In females, average antibody levels of all measurements were lower than males $(p>0.05)$. Anti-S antibody levels $14 \%$ increased at 38th week compared to 11th week (quantitative positivity threshold $\geq 0.8 \mathrm{U} / \mathrm{ml}$ ), and no cases were negative at 38 th week.

Conclusions Patients had $\geq 90 \%$ positivity after at least 9 months of symptoms, both anti-N and anti-S antibodies. In all samples, both anti-N and anti-S antibody levels were lower in females. The findings suggest that the quantitative values of anti-S antibodies remained high for at least 9 months and could provide protection.
\end{abstract}

Keywords Antibody · COVID-19 · Persistence $\cdot$ SARS-CoV-2

Mustafa Hacimustafaoglu

mkemal@uludag.edu.tr

1 Department of Public Health, Bursa Uludag University Medical Faculty, Bursa, Turkey

2 Department of Medical Microbiology, Bursa Uludag University Medical Faculty, Bursa, Turkey

3 Department of Pediatric Infectious Diseases, Bursa Uludag University Medical Faculty, Bursa, Turkey

4 Biochemistry and Clinical Biochemistry, Guven Tip Laboratuarı, Bursa, Turkey

5 Department of Infectious Diseases and Clinical Microbiology, Bursa Uludag University Medical Faculty, Bursa, Turkey

6 Department of Pediatric Infectious Diseases, Hacettepe University Medical Faculty, Ankara, Turkey

\section{Introduction}

COVID-19 is a disease that arises from the SARS-CoV-2 virus and exhibits wide spectrum clinical pictures. In December 2019, this disease was first identified as severe pneumonia cases in Wuhan, China's Hubei province [1, 2]. After the rapid spread of the epidemic, World Health Organization (WHO) declared a pandemic on March 11, 2020. Then, the first case was officially reported in Turkey on March 11, 2020 [3, 4]. The continual course of the pandemic, which poses a high-risk burden to the population, points to the importance of studies on the rate and durability of protective immunity after infection or vaccination.

Specific antibodies, as well as $\mathrm{T}$ and $\mathrm{B}$ cell-mediated responses against SARS-CoV-2, begin to be induced following infection. Studies have shown that some of these responses are protective, and the protection lasts for at least 
a few months. It is unknown whether all infected patients develop protective immunity and how long the protective antibody levels last after the infection [5]. Rare cases of re-infection have been reported in those after COVID-19, especially in the short term (such as within the first few months after initial infection) [6-9].

Serologically, antibody test positivity may be helpful in identifying individuals who could not be diagnosed by PCR or who had an asymptomatic/subclinical infection, as well as those who did not have a PCR test or were not diagnosed during active symptomatic infection. In addition, antibody test positivity can determine immunity against COVID-19 if it correlates with neutralizing antibodies. However, the protective antibody threshold titer could not be determined yet to prevent COVID-19 infection [10]. Nucleocapsid (N) and spike (S) structural proteins of SARS-CoV-2 play a role in the pathogenesis of the disease. Due to their immunogenic properties, $\operatorname{IgA}$, IgM, and/or IgG antibodies may develop against these antigenic structures. Therefore, these structures ( $\mathrm{S}$ or $\mathrm{N}$ ) are mostly used as viral antigenic target sites in diagnostic tests.

Knowing the persistence and protective features of antibodies against SARS-CoV-2 can determine the spreading parameters and ability to lead to an epidemic of the COVID19 infection in the population. Thus, it can provide populationbased preventive forecasting of the infection epidemiology. However, to our knowledge, there is no long-term study (such as 9-12 months) about the persistency and protective durability of SARS-CoV-2 antibody levels in the world.

In this study, we aimed to evaluate the course of antiSARS-CoV-2 total antibodies (anti-N and anti-S) during the 38 weeks after initial symptoms in patients with a history of possible (according to epidemiological, radiological, and non-specific laboratory findings) or confirmed (PCR positive) cases with COVID-19.

\section{Materials and methods}

Volunteers who had positive SARS-CoV-2 antibody results performed in a private laboratory and a history of possible/ confirmed symptomatic COVID-19 infection were invited to this study. This study was started after obtaining the ethical approval of the Bursa Uludağ University Faculty of Medicine Clinical Research Ethics Committee (2/9/20 date and 2020-15/6 number). This research was explained to the volunteers, after obtaining informed consent from the individuals who agreed to participate in this study; the volunteers were asked to fill in the prepared questionnaire that included 18 questions. Details of the COVID-19 infection history of the volunteers were questioned with clinical/epidemiologi$\mathrm{cal} /$ radiological and other laboratory results if available from their records.
Thirty-seven volunteers were included in this study. Their ages ranged from 18 to 57 years old. They had a history of symptomatic COVID-19 infection median 11 weeks ago (range 8-12 weeks) before the first blood sample was taken. First blood samples were taken at the median of 11 weeks after the onset of COVID-19 symptoms (sample no 1). Afterwards, blood samples were taken from each participant five times, at the median 15th (sample no 2), median 20th (sample no 3), median 29th (sample no 4), and median 38th (sample no 5) weeks. Serum samples were stored at $-20{ }^{\circ} \mathrm{C}$ until they were studied. Anti-nucleocapsid antigen total antibody (anti-N) against SARS-CoV-2 was studied in five serum samples. SARS-CoV-2 spike (S) antigen total antibody (anti-S) was studied in serum samples only in two serum samples (median 11th and median 38th weeks, sample nos. 1 and 5). During this study, COVID-19 vaccines were not available in Turkey; thus, none of the volunteers were vaccinated against COVID-19.

In this study, anti-N antibody (Roche, Elecsys SARSCoV-2 anti-N total) and anti-S antibody (Roche, Elecsys, Anti-SARS-CoV-2 S total) tests were used by the Cobas e 411 device (Roche diagnostics) in accordance with the manufacturer's instructions. These tests have been approved for use in routine patient diagnosis by the FDA, European Medicine Agency (EMA), and the Ministry of Health of Turkey. They have relatively higher sensitivity and specificity rates when compared with other similar antibody tests [11-13].

The sensitivity of the Roche, Elecsys SARS-CoV-2 anti-N total test was 100\% (95\% CI 88.3-100\%), and the specificity was $99.8 \%$ (95\% CI 99.7-99.9\%). For this test, samples with a cut-off index $(\mathrm{COI}) \geq 1$ were considered anti-N antibody positive [11, 12].

The sensitivity of the Roche, Elecsys, Anti-SARS-CoV-2 $S$ total test was reported as $96.6 \%$ (95\% CI 93.4-98.3\%); the specificity was $100 \%$ (95\% CI 99.9-100\%). This test is especially prominent with the detection of antibodies against the receptor-binding domain (RBD), which allows the $S$ protein to bind to the host cell ACE2 receptors, and gives quantitative results. Samples with a test result of $\geq 0.8 \mathrm{U} / \mathrm{ml}$ are considered to be positive $[11,13]$.

The tests used in this study make measurements with the electrochemiluminescence immunoassay (ECLIA) method. The automatization of the method reduces user and operational errors, and it is reported that it gives more specific and accurate results when compared to ELISA [14-16].

The Statistical Package for Social Sciences (SPSS) version 23.0 (SPSS Inc., Chicago, IL, USA) and Microsoft Excel programs were used for statistical analysis. Descriptive data were given as number, percentage, median, and mean \pm standard deviation. Student t-test, analysis of variance in repeated measures, and partial eta square for effect size were used for comparison of the means. The significance level was accepted as $p<0.05$ for all statistical tests. 


\section{Results}

The average age was $37.95 \pm 10.17$ years in females, and $43.47 \pm 11.07$ years in males ( $p=0.882$, not significant). Of 37 patients, $14(38 \%)$ patients were accepted as confirmed (PCR positive), and 23 (62\%) patients as possible (according to epidemiological, radiological, and non-specific laboratory findings) COVID-19 cases. Anti-N antibody measurements were made at the median 11, 15, 20, 29, and 38 weeks (totally five times) after the initial symptoms (Table 1).

A significant difference was found in the mean anti-N antibody levels of the participants during the follow-up $(p<0.05)$. Although there was a slight increase in the first two measurements (between the 11- and 15-week measurements), this increase was not significant $(p=0.472)$. The anti-N antibody level decreased significantly between subsequent measurements $(p=0.016$ between 15 and 20 weeks, $p=0.0009$ between 20 and 29 weeks and $p=0.049$ between 29 and 38 weeks). Approximately 1-year course of antibodies, when statistically estimated, the average anti-N antibody (COI) of 56.48 at week 11 has been calculated that it will decrease to 28.16 in 43-52 weeks and 20.48 in 53-62 weeks.

The mean anti-N antibodies in all five samples were lower in females than males, but the difference was not significant $(p>0.05)$. The distributions of average anti$\mathrm{N}$ antibody levels by gender in the consecutive weeks are presented in Graphic 1. Although there was no difference between the sexes in the average antibody levels concerning the general averages, there was a tendency of difference between the genders in the 15-20 weeks and
Table 2 Relationship between anti-N antibody levels in repeated measurements*

\begin{tabular}{lll}
\hline & $p$ & $\begin{array}{l}\text { Partial eta } \\
\text { squared } \\
(\eta p 2)\end{array}$ \\
\hline Between 11 and 15 weeks & .452 & 016 \\
Between 15 and 20 weeks & $\mathbf{. 0 2 0}$ & $\mathbf{. 1 4 6}$ \\
Between 20 and 29 weeks & $\mathbf{. 0 1 0}$ & $\mathbf{. 1 7 5}$ \\
Between 29 and 38 weeks & .052 & .104 \\
\hline
\end{tabular}

*Analysis of variance in repeated measures; partial eta square was used for effect size. Accordingly, a significant difference was found between females and males in the values between 15 and 20 weeks and between 20 and 29 weeks $(p<0.05$ and $\eta p 2>0.14$

20-29 weeks. Antibody levels were lower in females than in males between these weeks $(p<0.05)$. In the measurements with a difference, the effect of gender was large ( $\eta p 2>0.14)$ (Table 2).

The general increase (14\%) in the average anti-S antibodies between 11 and 38 weeks was not significant $(p=0.203)$. Between the sexes, the average anti-S antibodies were again lower in females but not significantly (Graphic 2) (Table 3).

The average anti-S antibody levels between 11 and 38 weeks (samples 1 and 5) are shown in Table 4. Accordingly, anti- $\mathrm{N}$ antibodies became negative in $8 \%$ (15\% in females, $0 \%$ in males) at 38 weeks compared to 11 weeks $(p>0.05)$. No negativity was observed in anti-S antibodies.
Table 1 The consecutive course of anti-N antibody levels between 11 and 38 weeks*

\begin{tabular}{llcrc}
\hline & $\begin{array}{l}\text { Sample week Average } \pm \text { SD } \\
(\text { min-max) }\end{array}$ & Median week & $\begin{array}{l}\text { Anti-N antibody } \\
\text { Average } \pm \text { SD }\end{array}$ & $p$ \\
\hline Sample no: 1 & $10.54 \pm 1.19(8-12)$ & 11 & F: $48.61 \pm 43.85$ & 0.76 \\
& & & M: $65.74 \pm 40.23$ & \\
Sample no: 2 & $14.97 \pm 1.21(13-17)$ & 15 & T: $56.48 \pm 42.53$ & \\
& & & F: $49.05 \pm 45.47$ & 0.79 \\
Sample no: 3 & $20.67 \pm 1.18(19-23)$ & 20 & M: $68.14 \pm 45.45$ & \\
& & & T: $57.82 \pm 45.85$ & \\
& & F: $41.49 \pm 42.33$ & 0.19 \\
Sample no: 4 & $29.19 \pm 1.85(26-33)$ & 29 & M: $64.31 \pm 51.31$ & \\
& & & T: $51.97 \pm 47.42$ & \\
& & F: $30.86 \pm 43.61$ & 0.17 \\
Sample no: 5 & $37.41 \pm 2.02(34-42)$ & 38 & M: $54.22 \pm 48.99$ & \\
& & & T: $41.59 \pm 47.01$ & \\
& & F: $26.14 \pm 41.22$ & 0.23 \\
\hline
\end{tabular}

$F$ female, $M$ male, $T$ total

*After initial symptoms 
Table 3 Distribution of anti-S antibody levels by gender

\begin{tabular}{llrl}
\hline $\begin{array}{l}\text { Median sample week } \\
\text { and average } \pm \text { SD }\end{array}$ & Gender $(n)$ & Average \pm SD U/ml & $p$ \\
\hline 11 weeks 102.32 \pm 87.68 & Female (20) & $92.57 \pm 79.58$ & $>0.05$ \\
& Male (17) & $113.79 \pm 97.57$ & \\
& Total (37) & $102.32 \pm 87.68$ & \\
38 weeks 116.58 \pm 94.16 & Female (20) & $115.44 \pm 94.50$ & $>0.05$ \\
& Male (17) & $117.91 \pm 96.65$ & \\
& Total (37) & $116.58 \pm 94.16$ & \\
\hline
\end{tabular}

\section{Discussion}

Different antibody measurement methods/tests for antigenic regions of SARS-CoV-2 are available. The tests usually measure the antibodies formed individually (IgG or IgM) or total $(\operatorname{IgG}+\operatorname{IgM})$. Although IgA-based antibody tests are also available, they are not recommended for routine use [10]. The specificity and sensitivity of the tests may differ. Unlike IgG antibody and total antibody tests, IgM antibody and $\operatorname{IgA}$ antibody tests generally have a specificity of less than 99 percent [16]. The anti-N and anti-S tests used in our study work with the ECLIA method and can be considered reliable since they show high sensitivity and specificity rates and a relatively narrow confidence interval $[11,15$, 16]. Regarding the COVID-19 antibody tests, the Infectious Diseases Society of America (IDSA) recommends using IgG
Distribution of anti-N antibody average values by gender

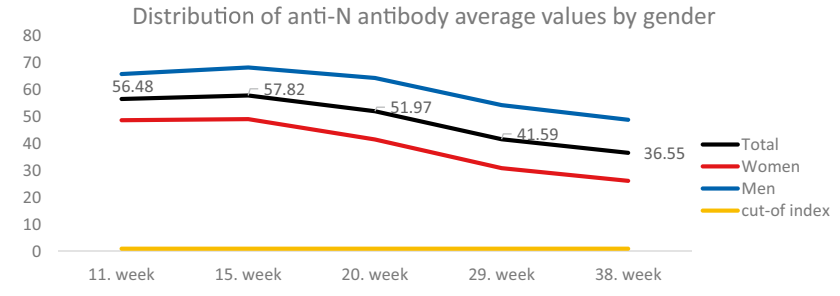

Fig. 1 Distribution of anti-N antibody average values by gender (COI cut-off index $>1$ )

only or total antibody tests since their accuracy is higher, instead of IgM only or IgA only tests [10, 16].

Cross-positive reactions (e.g., with antibodies against seasonal coronavirus) of some antibody tests used in the diagnosis of COVID-19 may lead to a potential problem [5, 17]. Neutralizing antibodies against SARS-CoV-2 and SARS-CoV-2 reactive CD4 T cells were also detected in individuals who did not have a SARS-CoV-2 infection. This may be due to possible seasonal coronavirus infection (common cold) and cross antigen positivity [18-21]. The possible effects of this pre-existing cross-reactive reaction on the confounding effect of the serological diagnosis of COVID-19 are unknown. Therefore, antibody measurement tests must be above a certain specificity (and also sensitivity) limit and be standardized to be used for diagnostic purposes. The CDC recommends that among the tests approved for use
Table 4 Comparison between 1 st and 5 th serum samples (between 11 and 38 weeks) of anti- $\mathrm{N}$ and anti-S antibodies

\begin{tabular}{lll}
\hline & $\begin{array}{l}\text { Anti-N antibodies* (difference } \\
\text { between } 11 \text { and } 38 \text { weeks) }\end{array}$ & $\begin{array}{l}\text { Anti-S antibodies* } \\
\text { (difference between } 11 \text { and } \\
\text { weeks) }\end{array}$ \\
\hline $\begin{array}{l}\text { Increased** } \\
\text { Female } \\
\text { Male }\end{array}$ & $2 / 20(10 \%)$ & $11 / 20(55 \%)$ \\
Total & $2 / 17(11.7 \%)$ & $13 / 17(76.4 \%)$ \\
Decreased** & $4 / 37(10.8 \%)$ & $15 / 37(40.5 \%)$ \\
Female & & $9 / 20(45 \%)$ \\
Male & $15 / 20(75 \%)$ & $4 / 17(23.5 \%)$ \\
Total & $15 / 17(88 \%)$ & $22 / 37(59.5 \%)$ \\
Negative at 38 weeks** & $30 / 37(81 \%)$ & 0 \\
Female & $3 / 20(15 \%)$ & 0 \\
Male & 0 & 0 \\
Total & $3 / 37(8.1 \%)$ & $\%+25$ \\
$\Delta$ average (difference $\%) * *$ & $\%-46$ & $\%+4$ \\
Female & $\%-26$ & $\%+14$ \\
Male & $\%-35$ & \\
Total & & \\
\hline
\end{tabular}

Anti-N measurement value averages are given as COI, and anti-S measurement value averages are given as $\mathrm{U} / \mathrm{ml}$ (quantitative). Due to the small number of patients, detailed statistical evaluations were not made

*Comparison of antibody values between 11 and 38 weeks

** It was calculated as 11 th-week antibody average value to 38 th-week average antibody value)/11th-week average antibody value 


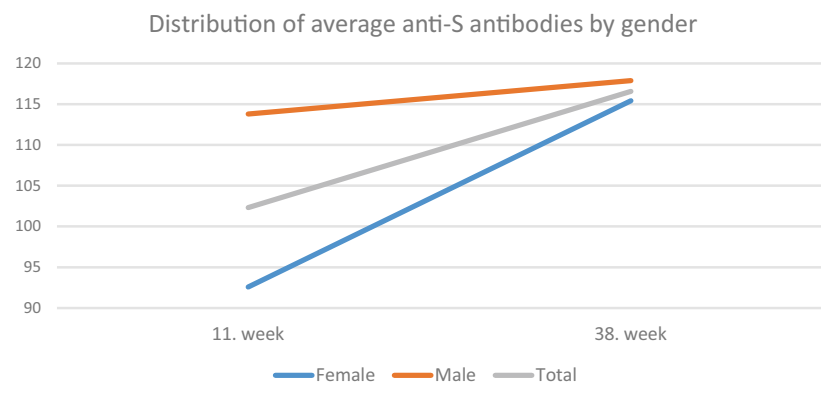

Fig. 2 Change in anti-S antibody averages. Average quantitative antibody values are given in $\mathrm{U} / \mathrm{ml}$ (positive threshold value $>0.8 \mathrm{U} / \mathrm{ml}$ )

for COVID-19, high specificity ( $\geq 99.5 \%$ ) ones should be preferred first [10, 22].

After COVID-19 infection, serological antibody positivity usually begins to develop around the first week, although it varies from patient to patient or according to the characteristics of the test used. Antibody levels usually reach the highest level in 3-4 weeks [22-24]. Therefore, 3-4 weeks after the onset of symptoms, checking the serology optimizes the accuracy of the test. In some cases, antibodies may decrease after 5 weeks. Thus, test sensitivity may be affected [16]. In a systematic review of 38 studies evaluating the sensitivity of serological tests overtime after the first symptoms in patients with COVID-19, IgM positivity was $23 \%$ at 1 week, $58 \%$ at 2 weeks, and $75 \%$ at 3 weeks,

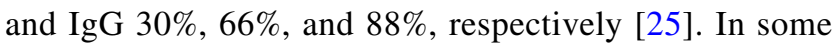
other studies, it has been suggested that the positive IgG rate approaches $100 \%$ between 16 and 20 days [26, 27]. Some studies suggest that most patients have no detectable antibodies 3 months after infection [28-31], while other studies have reported persistent, detectable IgG levels in most patients up to 5 months after infection [32-35]. For example, one study found that $\operatorname{IgG}$ levels and neutralizing antibodies decreased by an average of $75 \%$ in the early convalescent ( 8 weeks following infection) period after the acute stage of the disease. Moreover, in the early convalescent period, $40 \%$ of asymptomatic patients and $13 \%$ of symptomatic patients turned to be seronegative [28]. On the other hand, in Iceland, 1107 people that were found positive with anti-SARS-CoV-2 total Ig tests (e.g., using Roche anti-nucleoprotein total Ig, and Roche anti-S total and other tests; Wantai, EDI/Eagle, and Euroimmun) were followed up for antibody levels. It was found that titers gradually increased in the first 2 months after diagnosis (PCR positivity), formed a plateau for the next 2 months, and antibody levels were observed to persist for 4 months after initial symptomatic infection [32]. The duration of antibody persistency may possibly depend on the high initial antibody response and the severity of the infection [36]. It should also be kept in mind that individual differences may also occur.
Information on the duration of antibody responses against SARS-CoV-2 and whether the immunity is correlated with antibody levels is limited. In a study, a course of IgG antibodies was observed in 34 adults ( 20 women and 14 men) with a mean age of 43 . In this study, the first antibody test was performed after an average of 37 days (18-65 days) and the last antibody measurement was performed an average of 86 days (44-119 days) after symptoms. The half-life of $\operatorname{IgG}$ antibodies was 73 days (52-120 days) [29]. In another study, the antibody course was followed in 20 healthcare workers who were PCR positive COVID-19 infection. Between the $1 \mathrm{st}$ and 4 th months after the onset of symptoms, the antibody levels decreased, but the positivity continued, except for two people [37]. Similarly, in another study, it was shown that anti-S (anti-RBD) antibodies and neutralizing antibodies decreased significantly between 1.3 and 6.2 months after infection but were still detectable [38]. In the same study, neutralizing antibodies decreased five times 6.2 months after. However, there was no significant change in RBDspecific memory B cells at that time [38].

In our study, anti-N antibodies were acceptably high (mean COI: 36) for 38 weeks (about nine months) after the onset of symptoms, $35 \%$ decrease in average values compared to the 11 th week, and negative results $(\mathrm{COI}<1)$ in $8 \%$ of the cases. The statistical estimation revealed that anti-N antibodies would be persisted (average COI: 20 ) even at least 1 year (between 53 and 62 weeks) after symptomatic infection. Anti-S antibodies were observed to persist for 38 weeks (approximately 9 months) after the onset of symptoms (mean $116 \mathrm{U} / \mathrm{ml})$, and there was no negative result $(<0.8 \mathrm{U} / \mathrm{ml})$ in any case. Between 11 and 38 weeks after the symptom onset, the persistence of anti-S antibodies was more pronounced than anti-N antibodies in serial measurements. In this context, it was thought that quantitatively and acceptably high anti-S antibody levels could provide protection at about nine months after infection.

There are differences in the results of studies conducted on the persistence of SARS CoV-2 antibody responses. This may be due to the heterogeneous nature of the patients studied (such as asymptomatic, mild, or more severe diseases) or the use of different antibody tests in different studies. There are studies showing that patients with asymptomatic COVID-19 infection have lower antibody levels than symptomatic cases, and these antibodies begin to decrease or disappear earlier [28, 39-41]. In the study of Wang et al., evaluating the antibody response and neutralizing effects, it was observed that antibody levels were lower in patients with mild symptoms than those with symptoms of a moderate and severe infection; however, the neutralizing effects of these antibodies were similar in those disease groups [27]. It has been reported that antibody responses are related to the severity of the disease and that detectable neutralizing antibodies may not always develop in patients with mild 
infections [42, 43]. Antibody-related immune responses against $\mathrm{HCoV}-\mathrm{OC} 43$ and $\mathrm{HCoV}-\mathrm{HKU} 1$, which are among the seasonal coronaviruses and cause cold symptoms with non-specific and mild infections, decreased significantly within 1 year. However, severe SARS-CoV-1 infection produced longer-term antibodies and immunity [44]. In previous studies, the findings showed that circulating antibodies against SARS-CoV or MERS-CoV, which caused smaller epidemics years ago, last at least 1 year [45, 46]. There are studies showing that antibodies continue for more than 2 years after SARS-CoV infection [47-49]. Antibody responses in individuals with MERS-CoV infection confirmed by laboratory tests have been reported to last at least 34 months after infection [50]. SARS CoV-2 infection can be considered a disease with both mucosal and systemic findings concerning its pathogenesis. Systemic and relatively more intense symptomatic disease seen SARS-CoV- 1 and MERS-CoV can be expected to have a more widespread and strong immune response with the increased support of cellular immunity and also longer persistence of antibodies. Our results suggest that there may be a persistence of anti-N and anti-S antibodies for at least 9 months after symptomatic infection and this may also provide protection from re-infection.

In our study, both anti-N (26-45\% lower) and anti-S (2-18\% lower) antibody levels were lower in females than males. The difference was not significant in individual sample average measurements. However, in repeated measurements for anti-N antibodies, it was significantly lower in females between 15 and 20 weeks (between 2 nd and 3rd measurements) and between 20 and 29 weeks (between 3rd and 4 th measurements). The average age of menopause in Turkey is reported to be 45 [51]. No significance was found in antibody levels above and below 45 years of age in the additional analysis regarding age. The average levels for anti-S antibodies were similarly lower in females, but it was not significant. The tendency of the difference for anti-S antibodies between females and males partially decreased towards the 38 weeks. In one study, it was reported that neutralizing antibodies were detected higher in men. Clinical signs of COVID-19 were more severe in males [52]. However, to our knowledge, no study has been found on its relationship with antibodies. It can be speculated that the immune response may be higher in patients who are systemically symptomatic and more severely affected. However, larger studies are needed to investigate the effects of other factors, including hormonal factors.

Although the protective role of antibodies against SARSCoV-2 is not known precisely, they are generally considered to be correlated with antiviral immunity, and antibody levels can be expected to be associated with plasma viral neutralization activity [29]. Neutralizing antibodies usually decrease a few months after infection, but different results have been reported in various studies [28, 53, 54]. In one study of 121 recovering plasma donors with high initial neutralization/binding titers (1:80), the titers dropped slightly within 5 months but remained 1:80 in the vast majority [35]. In contrast, another study evaluated 149 patients (7\% hospitalized) with COVID-19, with high titers of neutralizing antibodies detected in only $1 \%$ after an average of 39 days after disease onset [53]. In the same study, RBD-specific binding specific $\mathrm{B}$ cells were detected in six patients, and it was determined that neutralizing antibodies also developed at high titers, regardless of the serum neutralizing antibody titer [53].

In addition to the presence of antibodies that develop after infection, the level of titers, how long they persist, and whether they are neutralizing and protective are also important. Following infection with SARS-CoV-2, most patients develop neutralizing and detectable serum antibodies mainly directed to the RBD of the viral spike (S) protein $[55,56]$. However, neutralizing antibody measurement is a labor-intensive and more expensive assessment, requires biosafety level three laboratory conditions, and may not be performed everywhere [52]. Studies have shown that neutralizing antibody titers are directly correlated with anti-N antibody titers, and especially antibodies developed against the RBD part of the S1 antigen (measured by Roche, Elecsys anti-SARS-Cov-2 S) [38, 57, 58]. Likewise, Chen et al. found antibody levels compatible with the neutralizing effect in their study in which they evaluated the antibody responses of 59 patients who had PCR-confirmed COVID-19 [40]. However, in one study, although the IgG type antibodies against SARS-Cov-2 remained stable for up to 105 days, only the neutralizing effects were observed in $31-45$ days. It has been found that it decreases slowly after peak days [59]. Antibody test positivity may indicate immunity if it correlates with neutralizing antibodies. However, a protective titer could not be determined clinically [10]. However, anti-S1 (Euroimmun, ELISA, anti-SI) and anti-NP antibody (Abbott, ELISA, anti-NP) results showed a good correlation with neutralizing antibodies, and it was reported that this correlation was better with anti-S antibodies [25, 42]. In another study, 12,541 healthcare workers were looked for baseline SARS-CoV-2 antibodies, and positive and negative ones were monitored for COVID-19 development for 6 months. In 1117 people who were seropositive (positive for SARS-CoV-2 anti-S and anti-N antibody) suggesting a previous infection, developed less infection (PCR confirmed) in the 6 months after the test, compared to the control (seronegative persons/no previous disease) group ( 0.13 versus 1.09 cases per 10,000 patientdays). Also, no symptomatic infection developed in any individual with anti-S antibodies [60].

In light of the previous studies, it can be said that antiSARS-CoV-2 antibodies generally correlate with neutralizing antibodies developed against SARS-CoV-2, and this 
correlation is better with anti-S antibodies. In this context, the presence of anti-S antibodies in sufficient concentrations can predict protection from COVID-19. Our study, to our knowledge, is the longest antibody follow-up study. Anti-N antibodies were detected approximately more than 9 months after the symptom onset; it was still positive in $92 \%$ of the cases. It was also observed that anti-S antibodies still persisted more than 9 months (mean $116 \mathrm{U} / \mathrm{ml}$, cut-off level; $\geq 0.8 \mathrm{U} / \mathrm{ml}$ ) and did not turn to be negative in any of the cases at that time.

This study has some limitations. Our study covers approximately 9 months after infection, and the level up to nearly 1 year (62 weeks) was statistically estimated. Although regular follow-up of all cases for nearly nine months is a strong side of the study, the lack of follow-up for a longer period can be considered as a limitation. One of the limitations of the study is that some cases are possible cases (COVID-19 PCR negative). Another limitation is that anti-S could not be tested in every five consecutive serum samples where anti-N was measured. In addition, the low number of cases included in this study might lead to some statistical analysis not being strong.

In conclusion, antibody (anti-N and anti-S) levels with confirmed and/or possible COVID-19 cases evaluated consecutive serum samples between 11 and 38 weeks after the onset of symptoms. Anti-SARS-CoV-2 antibodies (both anti-N and anti-S) were still detectable for a longer period (more than 9 months on average) than other studies. Antibody positivity continued in $\geq 90 \%$ of the cases, and this could provide protection against re-infection. In addition, both anti-N and anti-S antibody levels were consistently lower in women in all samples.

Acknowledgements We cordially thank Dr. Neslihan Onder-Ozdemir (Bursa Uludag University) for her valuable contribution regarding academic English editing of this research article.

\section{Declarations}

Ethical approval This study was started after obtaining the ethical approval of the Bursa Uludağ University Faculty of Medicine Clinical Research Ethics Committee (2/9/20 date and 2020-15/6 number).

Conflict of interest The authors declare no competing interests.

\section{References}

1. Ren LL, Wang YM, Wu ZQ et al (2020) Identification of a novel coronavirus causing severe pneumonia in human: a descriptive study. Chin Med J 133:1015-1024. https://doi.org/10.1097/CM9. 0000000000000722

2. Huang C, Wang Y, Li X et al (2020) Clinical features of patients infected with 2019 novel coronavirus in Wuhan. China Lancet 395:497-506. https://doi.org/10.1016/S0140-6736(20)30183-5
3. Timeline: WHO's COVID-19 response (2020) https://www.who. int/emergencies/diseases/novel-coronavirus-2019/interactivetimeline\#! Accessed 16.02.2021

4. TC Sağlık Bakanlığı Halk Sağlığı Müdürlüğü Covid-19 (SARSCoV-2 Enfeksiyonu) Genel Bilgiler (2020) Epidemiyoloji ve Tanı Rehberi. 7 Aralık https://covid19.saglik.gov.tr/TR-66337/ genel-bilgiler-epidemiyoloji-ve-tani.html. Accessed 16.02.2021

5. McIntosh K, Hirsch MS, Bloom A (2021) Coronavirus disease 2019 (COVID-19): Epidemiology, virology, and prevention. https://www.uptodate.com/contents/coronavirus-disease2019-covid-19-epidemiology-virology-and-prevention. Accessed 21.01.2021

6. To KK, Hung IF, Ip JD et al (2020) COVID-19 re-infection by a phylogenetically distinct SARS-coronavirus-2 strain confirmed by whole genome sequencing. Clin Infect Dis. https://doi.org/ 10.1093/cid/ciaa1275

7. Van Elslande J, Vermeersch P, Vandervoort K et al (2020) Symptomatic SARS-CoV-2 reinfection by a phylogenetically distinct strain. Clin Infect Dis. https://doi.org/10.1093/cid/ ciaa1330

8. Gupta V, Bhoyar RC, Jain A et al (2020) Asymptomatic reinfection in two healthcare workers from India with genetically distinct SARS-CoV-2. Clin Infect Dis. https://doi.org/10.1093/ cid/ciaa1451

9. Tillett RL, Sevinsky JR, Hartley PD et al (2021) Genomic evidence for reinfection with SARS-CoV-2: a case study. Lancet Infect Dis 21:52-58. https://doi.org/10.1016/S1473-3099(20) 30764-7

10. Caliendo AM, Hanson KE, Hirsch MS et al (2021) Coronavirus disease 2019 (COVID-19): Diagnosis. https://www.uptodate.com/ contents/coronavirus-disease-2019-covid-19-diagnosis. Accessed 04.02.2021

11. EUA Authorized Serology Test Performance. https://www.fda. gov/medical-devices/emergency-situations-medical-devices/euaauthorized-serology-test-performance. Accessed 04.02.2021

12. Elecsys Anti-SARS-CoV-2. https://www.fda.gov/media/137605/ download. Accessed 16.02.2021

13. Elecsys Anti-SARS-CoV-2 S. https://diagnostics.roche.com/ tr/tr/products/params/elecsys-anti-sars-cov-2-s.html. Accessed 03.02 .2021

14. Nivedhita G, Brundha MP (2020) Eclia Test- Review. IJFMT 14:5067-73. https://doi.org/10.37506/ijfmt.v14i4.12426

15. Chang L, Zhao J, Guo F et al (2020) Comparative evaluation and measure of accuracy of ELISAs, CLIAs and ECLIAs for he Detection of HIV Infection among Blood Donors in China. Can J Infect Dis Med Microbiol. https://doi.org/10.1155/2020/2164685

16. Hansen KE, Caliendo AM, Arias CA et al (2020) Infectious Diseases Society of America Guidelines on the Diagnosis of COVID19: Serologic Testing. https://www.idsociety.org/practice-guideline/ covid-19-guideline-serology/. Accessed 21.01.2021

17. Lustig Y, Keler S, Kolodny R et al (2020) Potential antigenic cross-reactivity between SARS-CoV-2 and Dengue viruses. Clin Infect Dis. https://doi.org/10.1093/cid/ciaa1207

18. Grifoni A, Weiskopf D, Ramirez SI et al (2020) Targets of T cell responses to SARS-CoV-2 coronavirus in humans with COVID19 disease and unexposed individuals. Cell181:1489-501. https:// doi.org/10.1016/j.cell.2020.05.015

19. Mateus J, Grifoni A, Tarke A et al (2020) Selective and crossreactive SARS-CoV-2 T cell epitopes in unexposed humans. Science 370:89-94. https://doi.org/10.1126/science.abd3871

20. Braun J, Loyal L, Frentsch M et al (2020) SARS-CoV-2-reactive $\mathrm{T}$ cells in healthy donors and patients with COVID-19. Nature 587:270-274. https://doi.org/10.1038/s41586-020-2598-9

21. Ng KW, Faulkner N, Cornish GH et al (2020) Preexisting and de novo humoral immunity to SARS-CoV-2 in humans. Science 370:1339-1343. https://doi.org/10.1126/science.abe1107 
22. Centers for Disease Control and Prevention (2020) Interim guidelines for COVID-19 antibody testing in clinical and public health settings. https://www.cdc.gov/coronavirus/2019-ncov/ lab/resources/antibody-tests-guidelines.html?deliveryName $=$ USCDC_2067-DM29085. Accessed 29.01.2021

23. Fang FC, Naccache SN, Greninger AL (2020) The laboratory diagnosis of coronavirus disease 2019-frequently asked questions. Clin Infect Dis 71:2996-3001. https://doi.org/10.1093/cid/ ciaa742

24. Cheng MP, Yansouni CP, Basta NE et al (2020) Serodiagnostics for severe acute respiratory syndrome-related coronavirus 2: a narrative review. Ann Intern Med. https://doi.org/10.7326/M20-2854

25. Deeks JJ, Dinnes J, Takwoingi Y et al (2020) Antibody tests for identification of current and past infection with SARS-CoV-2. Cochrane Database Syst Rev 6:CD013652. https://doi.org/10. 1002/14651858.CD013652

26. Caturegli G, Materi J, Howard BM et al (2020) Clinical validity of serum antibodies to SARS-CoV-2: a case-control study. Ann Intern Med. https://doi.org/10.7326/M20-2889

27. Wang X, Guo X, Xin Q et al (2020) Neutralizing antibodies responses to SARS-CoV-2 in COVID-19 inpatients and convalescent patients. Clin Infect Dis. https://doi.org/10.1093/cid/ ciaa721

28. Long QX, Tang XJ, Shi QL et al (2020) Clinical and immunological assessment of asymptomatic SARS-CoV-2 infections. Nat Med 26:1200-1204. https://doi.org/10.1038/s41591-020-0965-6

29. Ibarrondo FJ, Fulcher JA, Goodman-Meza D et al (2020) Rapid decay of anti-SARS-CoV-2 antibodies in persons with mild Covid-19. N Engl J Med 383:1085-1087. https://doi.org/10.1056/ NEJMc2025179

30. Patel MM, Thornburg NJ, Stubblefield WB et al (2020) Change in antibodies to SARS-CoV-2 over 60 days among health care personnel in Nashville. Tennessee JAMA 324:1781-1782. https:// doi.org/10.1001/jama.2020.18796

31. Perreault J, Tremblay T, Fournier MJ et al (2020) Waning of SARS-CoV-2 RBD antibodies in longitudinal convalescent plasma samples within 4 months after symptom onset. Blood 136:2588-2591. https://doi.org/10.1182/blood.2020008367

32. Gudbjartsson DF, Norddahl GL, Melsted P et al (2020) Humoral immune response to SARS-CoV-2 in Iceland. N Engl J Med. 383:1724-34. https://doi.org/10.1056/NEJMMoa2026116

33. Isho B, Abe KT, Zuo M et al (2020) Persistence of serum and saliva antibody responses to SARS-CoV-2 spike antigens in COVID-19 patients. Sci Immunol. https://doi.org/10.1126/ sciimmunol.abe5511

34. Iyer AS, Jones FK, Nodoushani A et al (2020) Persistence and decay of human antibody responses to the receptor binding domain of SARS-CoV-2 spike protein in COVID-19 patients. Sci Immunol. https://doi.org/10.1126/sciimmunol.abe0367

35. Wajnberg A, Amanat F, Firpo A et al (2020) Robust neutralizing antibodies to SARS-CoV-2 infection persist for months. Science 370:1227-30. https://doi.org/10.1126/science.abd7728

36. Self WH, Tenforde MW, Stubblefield WB et al (2020) Decline in SARS-CoV-2 antibodies after mild infection among frontline health care personnel in a multistate hospital network-12 states, April-August 2020. MMWR Morb Mortal Wkly Rep 69:1762-6. https://doi.org/10.15585/mmwr.mm6947a2

37. Höller DO, Eigentler A, Weseslindtner L et al (2020) Antibody kinetics in primary- and secondary-care physicians with mild to moderate SARS-CoV-2 infection. Emerg Microbes Infect 9:16921694. https://doi.org/10.1080/22221751.2020.1793690

38. Gaebler C, Wang Z, Lorenzi JCC et al (2021) Evolution of antibody immunity to SARS-CoV-2. Nature. https://doi.org/10.1038/ s41586-021-03207-w

39. Zhao J, Yuan Q, Wang $\mathrm{H}$ et al (2020) Antibody responses to SARS-CoV-2 in patients with novel coronavirus disease 2019.
Clin Infect Dis 71:2027-2034. https://doi.org/10.1093/cid/ ciaa344

40. Chen X, Pan Z, Yue S et al (2020) Disease severity dictates SARSCoV-2-specific netralizing antibody responses in COVID-19. Nature. https://doi.org/10.1038/s41392-020-00301-9

41. Wang Y, Zhang L, Sang L et al (2020) Kinetics of viral load and antibody response in relation to COVID-19 severity. J Clin Invest 130:5235-5244. https://doi.org/10.1172/JCI138759

42. Rijkers G, Murk JL, Wintermans B et al (2020) Differences in antibody kinetics and functionality between severe and mild severe acute respiratory syndrome coronavirus 2 infections. J Infect Dis 222:1265-1269. https://doi.org/10.1093/infdis/jiaa463

43. Lynch KL, Whitman JD, Lacanienta NP et al (2021) Magnitude and kinetics of anti-SARS-CoV-2 antibody responses and their relationship to disease severity. Clin Infect Di 27:301-308. https://doi.org/ 10.1093/cid/ciaa979

44. Chan KH, Chan JFW, Tse H et al (2013) Cross-reactive antibodies in convalescent SARS patients' sera against the emerging novel human coronavirus EMC (2012) by both immunofluorescent and neutralizing antibody tests. J Infect 67:130-140. https://doi.org/ 10.1016/j.jinf.2013.03.015

45. Cao WC, Liu W, Zhang PH et al (2007) Disappearance of antibodies to SARS-associated coronavirus after recovery. N Engl J Med 357:1162-1163. https://doi.org/10.1056/NEJMc070348

46. Choe PG, Perera RAPM, Park WB et al (2017) MERS-CoV antibody responses 1 year after symptom onset, South Korea, 2015. Emerg Infect Dis 23:1079-1084. https://doi.org/10.3201/eid2307. 170310

47. Guo X, Guo Z, Duan C et al (2020) Long-term persistence of IgG antibodies in SARS-CoV infected healthcare workers. MedRxiv. https://doi.org/10.1101/2020.02.12.20021386

48. Wu LP, Wang NC, Chang YH et al (2007) Duration of antibody responses after severe acute respiratory syndrome. Emerg Infect Dis 13:1562-1564. https://doi.org/10.3201/eid1310.070576

49. Huang AT, Carreras BG, Hitchings MDT et al (2020) A systematic review of antibody mediated immunity to coronaviruses: kinetics, correlates of protection, and association with severity. Nat Commun 17:4704. https://doi.org/10.1038/s41467-020-18450-4

50. Payne DC, Iblan I, Rha B et al (2016) Persistence of antibodies against middle east respiratory syndrome coronavirus. Emerg Infect Dis 22:1824-1826. https://doi.org/10.3201/eid2210.160706

51. Özdemir O, Çöl M (2004) The age at menopause and associated factors at the health center area in Ankara. Turkey Maturitas 49:211-219. https://doi.org/10.1016/j.maturitas.2004.01.013

52. Boonyaratanakornkit J, Morishima C, Selke S et al (2021) Clinical, laboratory and temporal predictors of neutralizing antibodies to SARS-Cov-2 after COVID-19. J Clin Invest 131(3):e144930. https://doi.org/10.1172/JCI144930

53. Robbiani DF, Gaebler C, Muecksch F et al (2020) Convergent antibody responses to SARS-CoV-2 in convalescent individuals. Nature 584:437-442. https://doi.org/10.1038/s41586-020-2456-9

54. Wang K, Long QX, Deng HJ et al (2020) Longitudinal dynamics of the neutralizing antibody response to SARS-CoV-2 infection. Clin Infect Dis. https://doi.org/10.1093/cid/ciaa1143

55. Report of the WHO-China Joint Mission on Coronavirus DIsease 2019 (COVID-2019) (2020) http://www.who.int/docs/defaultsource/coronaviruse/who-china-joint-mission-on-covid-19-finalreport.pdf. Accessed 21.01.2021

56. Guo L, Ren L, Yang S et al (2020) Profiling early humoral response to diagnose novel coronavirus disease (COVID-19). Clin Infect Dis 71:778-785. https://doi.org/10.1093/cid/ciaa310

57. To KKW, Tsang OTY, Leung WS et al (2020) Temporal profiles of viral load in posterior oropharyngeal saliva samples and serum antibody responses during infection by SARS-CoV-2: an observational cohort study. Lancet Infect Dis 20:565-574. https://doi. org/10.1016/S1473-3099(20)30196-1 
58. Kovac M, Risch L, Thiel S et al (2020) EDTA-anticoagulated whole blood for SARS-CoV-2 antibody testing by electrochemiluminescence immunoassay (ECLIA) and enzyme-linked immunosorbent assay (ELISA). Diagnostics (Basel) 10:593. https://doi. org/10.3390/diagnostics10080593

59. Isho B, Abe KT, Zuo M et al (2020) Mucosal versus systemic antibody responses to SARS-CoV-2 antigens in COVID-19 patients. medRxiv. https://doi.org/10.1101/2020.08.01.20166553
60. Lumley SF, O'Donnell D, Stoesser NE et al (2021) Antibody status and incidence of SARS-CoV-2 infection in health care workers. N Engl J Med 384:533-540. https://doi.org/10.1056/ NEJMoa2034545

Publisher's Note Springer Nature remains neutral with regard to jurisdictional claims in published maps and institutional affiliations. 